\title{
A survey of the knowledge, use, and adoption of emerging technologies by academics in an Open Distance Learning environment
}

\author{
B CHIMBO' AND M TEKERE ${ }^{2}$
}

\begin{abstract}
The realisation of the advantages offered by e-learning accompanied by the use of various emerging information technologies has resulted in a noticeable shift by academia towards e-learning. An analysis of the use, knowledge and adoption of emerging technologies by academics in an Open Distance Learning (ODL) environment at the University of South Africa (UNISA) was undertaken in this study. The aim of the study was to evaluate the use, knowledge and adoption of emerging e-learning technologies by the academics from the selected schools. The academics in the Schools of Arts, Computing and Science were purposively selected in order to draw on views of academics from different teaching and educational backgrounds. Questionnaires were distributed both electronically and manually. The results showed that academics in all the Schools were competent at the use of information technology tools and applications such as emailing, word-processing, Internet, myUnisa (UNISA's online teaching platform), and Microsoft PowerPoint and Excel. An evaluation of the awareness of different emerging technological tools showed that most academics were aware of Open Access Technologies, Social Networking Sites, Blogs, Video Games and Microblogging Platforms. While the level of awareness was high for these technologies, the use by the academics was low. At least $62.3 \%$ of the academics indicated willingness to migrate to online teaching completely and also indicated the need for further training on new technologies. A comparison of the different schools showed no statistically significant difference in the use, knowledge and willingness to adopt technology amongst the academics.
\end{abstract}

Keywords: UNISA, emerging technology, e-learning, open distance learning, willingness

Disciplines: Information Technology, education.

\section{Introduction}

With advances in information and e-learning technologies, academia has witnessed the growing need and challenges to migrate from known traditional methods to alternative technology-based teaching methods. E-learning, by definition, covers any electronicmediated learning which can be Internet, Intranet-based and Web-delivered teachinglearning systems with or without face-to-face contact between teacher and learner (Queiros, Pinto, Rodrigues, Lopes, Oliveira, 2009). The realisation of the advantages that e-learning brings has resulted in an extensive move towards e-learning, accompanied by the use of various emerging technological tools (AlShemmary, Niir \& Katheeth 2012; Delich, Kelly \& McIntosh, 2008). Advantages of e-learning include instant access to global resources, and quick and easy ways to update curricula, among others (A1Shemmary et al., 2012; Summaka, Baglibel \& Samancioglu, 2010; Kumar, Rose \& D’Silva, 2008; Siemens \& Tittenberger,

1. School of Computing, University of South Africa, Pretoria,chimbb@unisa.ac.za

2. Environmental Science Department, University of South Africa, Pretoria, tekerm@unisa.ac.za. 
2009; Dede, 1999). While e-learning is still elective or not fully utilised by various institutions, recent developments indicate that distance education institutions and academics have to adopt emerging e-learning technologies since they cannot escape the fact that migration to online e-learning is a reality (AlShemmary et al., 2012; Veletsianos, 2010; Kumar et al., 2008). Being prepared to adopt and use technology therefore becomes a must for open distance learning lecturers.

\section{Emerging e-learning technologies}

Properly implemented, emerging technologies in e-learning have the potential to change and improve education, allow for innovation in curricula, and reshape the nature of knowledge mobilisation in education (Dede, 1999; Delich et al., 2008; Arthur, Beecher, Elliot \& Newman, 2006). The term "emerging technologies" has become a "buzz word" in different domains such as commerce and academia, and as such it is worth defining it in the context of this study. Veletsianos (2010) proposed that emerging technologies could be defined as tools, concepts, innovations, and advancements utilised in diverse educational settings to serve various education-related purposes such as organisational, instructional and social. They cover a wide range of technologies that are designed for application in different sectors. However, the main focus here is on technologies that have an impact in the educational environment (Hegarty, 2004). Technology is always in upgrade for new applications and users despite being already established and should be seen as emerging within a specific context. Emerging e-learning technologies are therefore not necessarily new but can be old and new innovations that are still in their infancy or are evolving, or coming into being in terms of their application or adoption for certain purposes (Ng'ambi, Gachago, Ivala, Bozalek \& Watters, 2012; Veletsianos, 2010; Delich et al., 2008; Hegarty et al., 2003). Additionally, "new" and "old" technologies are evolving organisms that experience hype cycles (Veletsianos, 2010). Woodill (2006) listed up to fifty-two emerging e-learning technologies that can benefit learning. In this paper, the term emerging technologies will be used to refer to all new and old innovations that are being adopted by UNISA in its migration to academic instruction through e-learning.

\section{Role of academics}

In any implementation of academic innovations, academics are seen as a driving force behind the success of such moves (Lucas, 2006; Panda \& Mishra, 2007; Kumar et al., 2008). Acceptance of emerging e-learning technologies is essential if online delivery is to be effectively implemented. It is noted, however, that there are challenges encountered if there is generalisation and scaling up of educational innovations without taking into account the academics as stakeholders (Lucas, 2006). Such moves can be hindered by the beliefs, theories, values, assumptions and culture underlying their organisation's operating practices (Dede, 1999; Panda \& Mishra, 2007; Kumar et al., 2008, Summak et al., 2010). The willingness of academics to adopt emerging technologies can also be informed by their field of specialisation and how the technology makes their job easier. Those who do not perceive a great benefit are likely to resist or lag behind in the adoption of new technologies. There is, therefore, need to engage academics to be flexible and adapt to the changes.

With respect to the use of information technology, personal and behavioural factors identified to facilitate or prohibit computer usage among academics include attitude, perceived ease of use, perceived usefulness, self-efficacy and computer compatibility (Kumar et al., 2008; Wang \& Reeves, 2003). Environmental factors identified included subjective 
norms and job relevance (Kumar et al., 2008). There is a need for academics to accept the paradigm shift and engage in progressive mindset change and be willing to tap into all the best of opportunities that emerging e-learning technologies offer to learning (Panda \& Mishra, 2007).

\section{Factors that influence adoption}

Emerging interactive media can enable virtual communities that provide effective social support, which may lead to deeper behavioural changes in educational practices (Dede, 1999; Anand, Saxena, \& Saxena, 2012). Panda \& Mishra (2007) noted, however, that faculty attitude and motivation plays a significant role in the adoption of e-learning. Attitudinal predisposition is an important factor in the shift from traditional distance education to webenabled learning (Panda \& Mishra, 2007; Summak et al., 2010). It was also reported in Dede (1999) that it is generally difficult to change someone's professional mind set and change can be overwhelming to the academics. The successful adoption of emerging technologies particularly in developing countries where there are still a lot of disparities in terms of technological knowledge and access is also dependent on the academic's level of knowledge, access, willingness and readiness to adopt such technologies (Dede, 1999; Kumar et al., 2008; Summak et al., 2010). Altering deeply ingrained and strongly reinforced professional rituals takes more than an informational interchange of the kind typical in conferences and most professional development (Dede, 1999).

Implementation of new academic initiatives has been found to require that academics restructure their belief system (Ahmad, Basir \& Hassanein, 2004; Summak et al., 2010; Dede, 1999). Motivators to e-learning adoption include personal interest to use of technology, intellectual challenges and sufficient provision for technology infrastructure (Panda \& Mishra, 2007). Acceptance to adopt emerging technologies is essential if online delivery is to be effectively implemented. In a study on roles of organisational readiness for emerging technologies, Ogunyemi \& Johnston (2012) indicated that challenges encountered include lack of awareness, expertise, skills, change readiness, cost of adoption and integration with existing technologies. Reported barriers elsewhere to the uptake of emerging e-learning technology in higher education include; lack of time by practitioners, lack of technical expertise and understanding of use and benefits of the new tools (Lucas, 2006; Summak et al., 2010).

\section{Emerging e-learning technologies at UNISA}

UNISA as a mega distance educational university in Africa has embarked on the assertive use of technology in all aspects of its mandate, ranging from tuition development and delivery and academic management. In its strategic planning, UNISA advocates various emerging elearning technology tools in all academic aspects, including administration, courseware delivery, and formative and summative assessment (UNISA Revised Curriculum Policy, 2012). To this end, the e-learning platform, myUnisa, was adopted with the accompanying Sakai platform. Through myUnisa, the staff and student community can access news and general information about UNISA, administrative and support functions, course specific functions, online learning opportunities and many other resources. Social networks are also part of the myUnisa platform. UNISA has discovered that, by using technology as an open and distance learning (ODL) institution, it enhances students' problem solving abilities and it can reach students irrespective of student numbers, place and time (UNISA Revised 
Curriculum Policy, 2012). Through online student assessment, lecturers can provide feedback more effectively and timeously (Dede, 1999; Hegarty et al., 2005).

In light of the rapid development of technology and advocacy to migrate to e-learning at UNISA and elsewhere, it was important to undertake this study so as to enable us to have informed insights on the knowledge, use and adoption of emerging e-learning technologies by academics in different teaching disciplines. Academics in the Schools of Arts, Computing and Science were used as respondents.

\section{Research Questions}

The research questions guiding this study were:

i. What is the knowledge and use of selected emerging e-learning technologies by selected academics at UNISA?

ii. What are the perceived benefits of emerging e-learning technologies by the academics?

iii. How willing and ready are the selected academics in embracing emerging e-learning technologies in teaching?

iv. How does educational and teaching specialisation affect the use, willingness and readiness to adopt emerging e-learning technologies?

\section{Research Approach}

This was a quantitative and descriptive study. Quantitative data was required to answer the research questions both in terms of the frequencies of the knowledge and use of emerging technologies by academics and how willing and ready the selected academics were in embracing emerging technologies. Descriptive research, also known as statistical research, which describes data and characteristics about the population or phenomenon being studied, was used as it answers the questions who, what, where, when and how. Thus, based on the above, the two research designs were appropriate for the study as it was important to gauge the knowledge, use, willingness and readiness of academics in adopting emerging technologies.

This study was transdisciplinary in nature, encompassing respondents from various disciplines. Trans disciplinary implies a research strategy that crosses many disciplinary boundaries to create a rounded approach. It applies to research efforts focused on problems that cross the boundaries of two or more disciplines. In this study, we looked at e-learning as a concept which academics with different academic backgrounds in sciences and humanities were involved in. The concepts or methods of e-learning that were originally developed by one discipline are now used across many disciplines.

\section{Participants}

The study was conducted at the University of South Africa (UNISA), and the Schools of Computing, Science and Arts were purposively selected to represent academics from different academic backgrounds and teaching areas, i.e. sciences and humanities. All fixed-contract and permanent academic members of staff in the schools were used as the study population. The questionnaires were distributed electronically to all 346 academics in the schools, but some were distributed manually (printed and handed to individuals who had indicated that preference). Details of the distribution of academics and departments in the Schools are given in Table 1. 
Table 1: Distribution of departments and academics in the Schools of Computing, Science and Arts at UNISA (Source: UNISA HRIS, March 2013).

\begin{tabular}{|l|l|l|l|l|}
\hline No: & School & Departments & $\begin{array}{l}\text { Total No. of } \\
\text { academics in each } \\
\text { department }\end{array}$ & $\begin{array}{l}\text { Total No. of } \\
\text { Academic Staff }\end{array}$ \\
\hline 1. & Computing & Computing & 77 & 77 \\
\hline 2. & Science & $\begin{array}{l}\text { i) Statistics } \\
\text { ii) Chemistry } \\
\text { iii) Physics } \\
\text { iv) Mathematical Science }\end{array}$ & $\begin{array}{l}\text { i) } 12 \\
\text { ii) } 30 \\
\text { iii) } 18 \\
\text { iv) } 28\end{array}$ & 88 \\
\hline 3. & Arts & $\begin{array}{l}\text { i) Afrikaans } \\
\text { ii) Information Science } \\
\text { iii) Classics and Work }\end{array}$ & $\begin{array}{l}\text { i) } 22 \\
\text { ii) } 18 \\
\text { iii) } 26\end{array}$ & \\
& $\begin{array}{l}\text { Languages } \\
\text { iv) African Languages } \\
\text { v) Communication Science } \\
\text { vi) English }\end{array}$ & $\begin{array}{l}\text { iv) } 20 \\
\text { v) } 40 \\
\text { vii) Linguistics } 40\end{array}$ & vii) 15 \\
\hline
\end{tabular}

\section{Research instrument and Data collection}

Questionnaires were used to collect data and the questions covered aspects that included:

- Personal information (gender, age, etc.);

- Qualifications and areas of teaching responsibilities;

- Knowledge and use of available Internet/myUnisa-based techniques;

- Factors affecting willingness, such as time constraints, knowledge to create learning activities online, educational knowledge background, and lack of awareness on what can be taught with emerging techniques; and

- Availability of support, authenticity, perceived benefits/advantages and disadvantages of emerging e-learning technologies.

The emerging e-learning technologies evaluated were:

- Cell/mobile phones and devices;

- Open Access Technologies, e.g. myUnisa, Blackboard, Mystats lab, Google chat, Blogs, Video games, Wikis and Wiki books;

- Word processing and publishing software, e.g. Microsoft PowerPoint, Word, and Excel;

- The World Wide Web and email;

- Social Networking Sites e.g. Facebook;

- Open Educational Resources and Pod and video casts, Pod usage production models;

- Virtual worlds, e.g. the Sims online;

- Data mashups;

- Online grassroots video; and

- Pedagogical agents e.g. Adele, Skype, Digital libraries, Webinar.

The fixed-term contract and permanent academic staff in the Schools were selected for this study. A pilot study was undertaken during the development of the questionnaire to test the 
reliability upon re-testing of the same respondents during the study and to see if the instrument was sufficient in gathering all the relevant information as required. This study received ethical clearance from the College of Science Engineering and Technology (CSET) and informed consent was sought from the participants before the study.

\section{Data analysis}

Data from the questionnaires were captured in Excel and coded. A statistical analysis and graphics software package (SPSS) was used to apply descriptive statistical techniques on the data. The summary of the data was presented in the form of frequency tables and charts, followed by their discussion and interpretation.

\section{Results analysis and interpretation}

Out of 346 questionnaires distributed, only 101 were received back, giving a response rate of $29.2 \%$, which gives us an acceptable and adequate response rate to produce useful results (Leedy \& Ormrod, 2010).

\section{Demographic Profiles}

From a total of 101 respondents who participated, the distribution of the respondents by School was $20.8 \%$ from the School of Science, 38.6\% from the School of Computing, and $40.6 \%$ from the School of Arts. The School of Arts had the highest number of respondents. The distribution of respondents per department was as indicated in Table 2.

Table 2: Distribution of respondents per department in the Schools $(\mathrm{N}=101)$

\begin{tabular}{|l|l|l|}
\hline Departments & Frequency & $(\%)$ \\
\hline School of Science & & \\
\hline Mathematical Science & 5 & 4.9 \\
\hline Chemistry & 3 & 3.0 \\
\hline Physics & 4 & 4.0 \\
\hline Statistics & 9 & 8.9 \\
\hline & & \\
\hline School of Computing & & \\
\hline Computing & 39 & 38.6 \\
\hline & & \\
\hline School of Arts & & \\
\hline Afrikaans & 8 & 7.9 \\
\hline Information Science & 6 & 5.9 \\
\hline Classics and Work Languages & 3 & 3.0 \\
\hline African Languages & 5 & 5.0 \\
\hline Communication Science & 6 & 5.9 \\
\hline English & 2 & 2.0 \\
\hline Linguistics & 11 & 10.9 \\
\hline & & \\
\hline Total & 101 & 100.0 \\
\hline
\end{tabular}

100 respondents indicated their gender status. Fifty-two percent (52\%) of the academics were males, and forty-eight percent (48\%) were females. The ratio of male to female respondents was therefore almost $1: 1$. 
All the respondents indicated their academic positions as shown in Table 3 . The majority of the respondents were senior lecturers, followed by lecturers. The distribution of respondents was in line with UNISA academic staff distribution, where the majority of the academic staff is senior lecturers and lecturers (UNISA HRIS, March, 2013).

Table 3: Distribution of academics at UNISA and the respondents' positions of employment

\begin{tabular}{|l|l|l|l|l|}
\hline Position & $\begin{array}{l}\text { Total No of } \\
\text { Academics at } \\
\text { UNISA }\end{array}$ & $\begin{array}{l}\text { \% Total No of } \\
\text { Academics at } \\
\text { UNISA }\end{array}$ & $\begin{array}{l}\text { Frequency of } \\
\text { respondents per } \\
\text { position }\end{array}$ & $\begin{array}{l}\text { \% of } \\
\text { respondents }\end{array}$ \\
\hline Junior Lecturer & 75 & 4.96 & 22 & 21.8 \\
\hline Lecturer & 451 & 29.81 & 25 & 24.7 \\
\hline Senior Lecturer & 501 & 33.11 & 32 & 31.8 \\
\hline Associate Professor & 211 & 13.95 & 6 & 5.9 \\
\hline Professor & 275 & 18.18 & 8 & 7.9 \\
\hline Research assistant & Data not provided & & 4 & 4.0 \\
\hline Postgraduate assistant & Data not provided & & 4 & 4.0 \\
\hline
\end{tabular}

(Source: UNISA HRIS, March 2013)

The age distribution of the respondents showed that most of the academics that responded were within the age group of 31 to 40 years as indicated in Figure 1. Overall, respondents were more or less evenly distributed across the age groups. This was important as it meant that the responses for the study were evenly drawn across the different age groups.

Figure 1: Age distribution of respondents $(\mathrm{N}=99)$

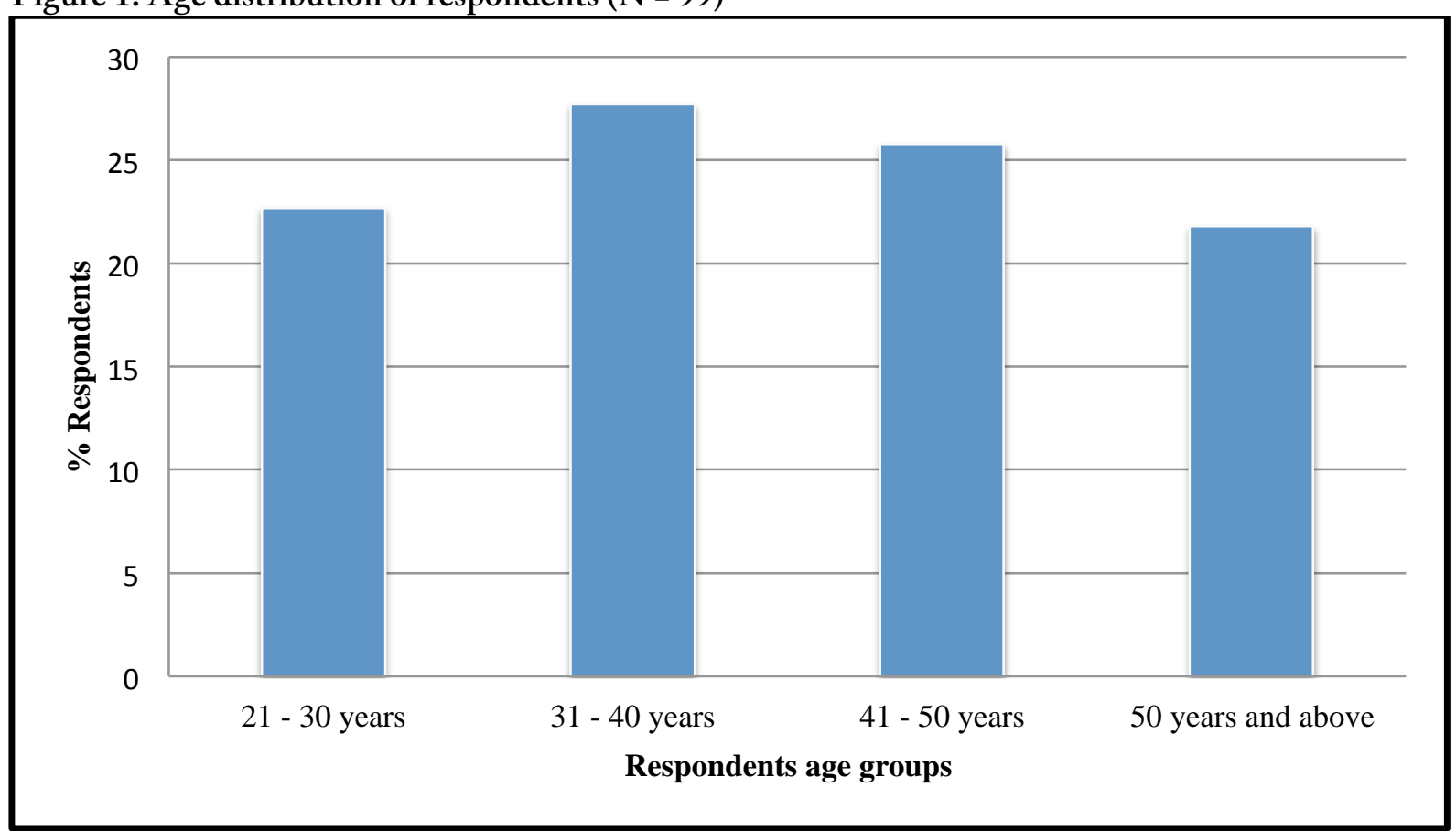

Ninety-eight responses were valid when it comes to teaching experience at UNISA. Fifty one percent of the respondents had less than 5 years teaching experience, $15.9 \%$ had 5 to 10 years of teaching experience and $30.7 \%$ had above 10 years teaching experience. The results show that there was an almost equal distribution of those less experienced (below 5 years) and experienced ( 5 years and more). 
The distribution of respondents in terms of teaching area as shown in Figure 2 showed that most respondents taught languages, followed by Computing and Natural Sciences. Communication and Information Sciences were the areas where the least number of respondents taught. The remainder of the responses (16.7\%) were not indicated within these major teaching area groups.

Figure 2: Distribution of respondents in terms of teaching areas

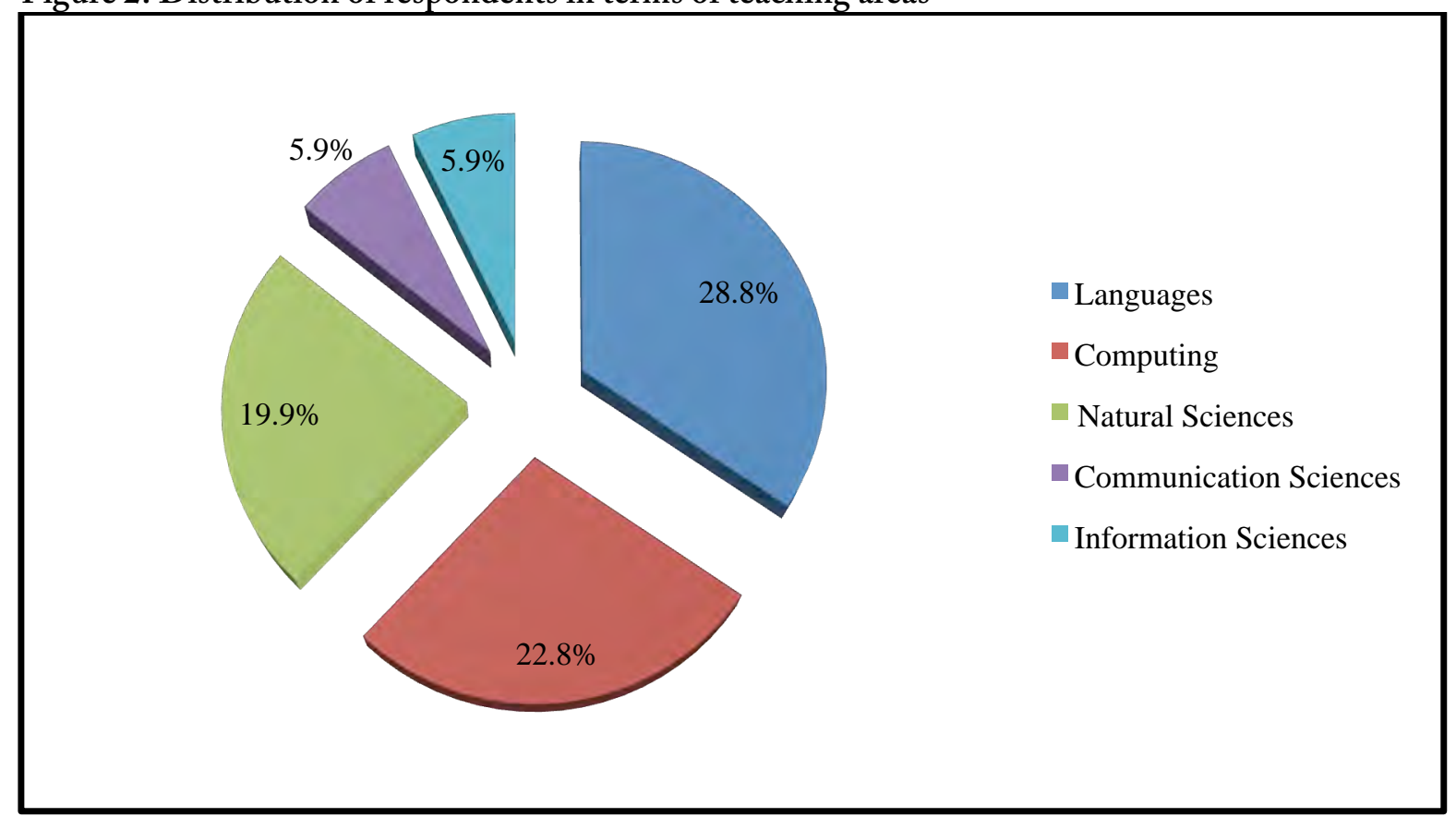

In terms of the courses taught by the respondents, $67.3 \%$ of the courses were for undergraduate, $26.9 \%$ were honours courses, and the remaining $5.8 \%$ were either Masters or Doctoral studies.

Ninety-eight respondents indicated their educational background. The information is shown in Table 4. This was a multiple response question. Most of the respondents' areas of specialisation were in Computer Sciences, Humanities and Social Sciences. This is attributed to the fact that $80 \%$ of the respondents were from the schools of Computing and Arts.

Table 4: Respondents' educational background $(\mathrm{N}=98)$

\begin{tabular}{|l|l|l|}
\hline Area & Frequency & \% of Cases \\
\hline Humanities and Social Sciences & 47 & 48.0 \\
Computing Sciences & 37 & 37.8 \\
Natural Sciences & 16 & 16.3 \\
Engineering Studies & 7 & 7.1 \\
Human movement sciences & 1 & 1.0 \\
Business Studies & 1 & 1.0 \\
Economics & 1 & 1.0 \\
Commercial Studies & 1 & 1.0 \\
\hline
\end{tabular}

The respondents' competences in six selected ICT resources are indicated in Figure 3. Information and communications technologies (ICT) are defined, as a "diverse set of technological tools and resources used to communicate, and to create, disseminate, store, and manage information" (Blurton 1999:46), and they encompass a wide range of rapidly evolving technologies including software applications such as email, word, PowerPoint and excel as 
well as digital technologies, such as computers, information networks (Internet, the World Wide Web, intranets and extranets) etc.

Figure 3: Competence of respondents in ICT resources

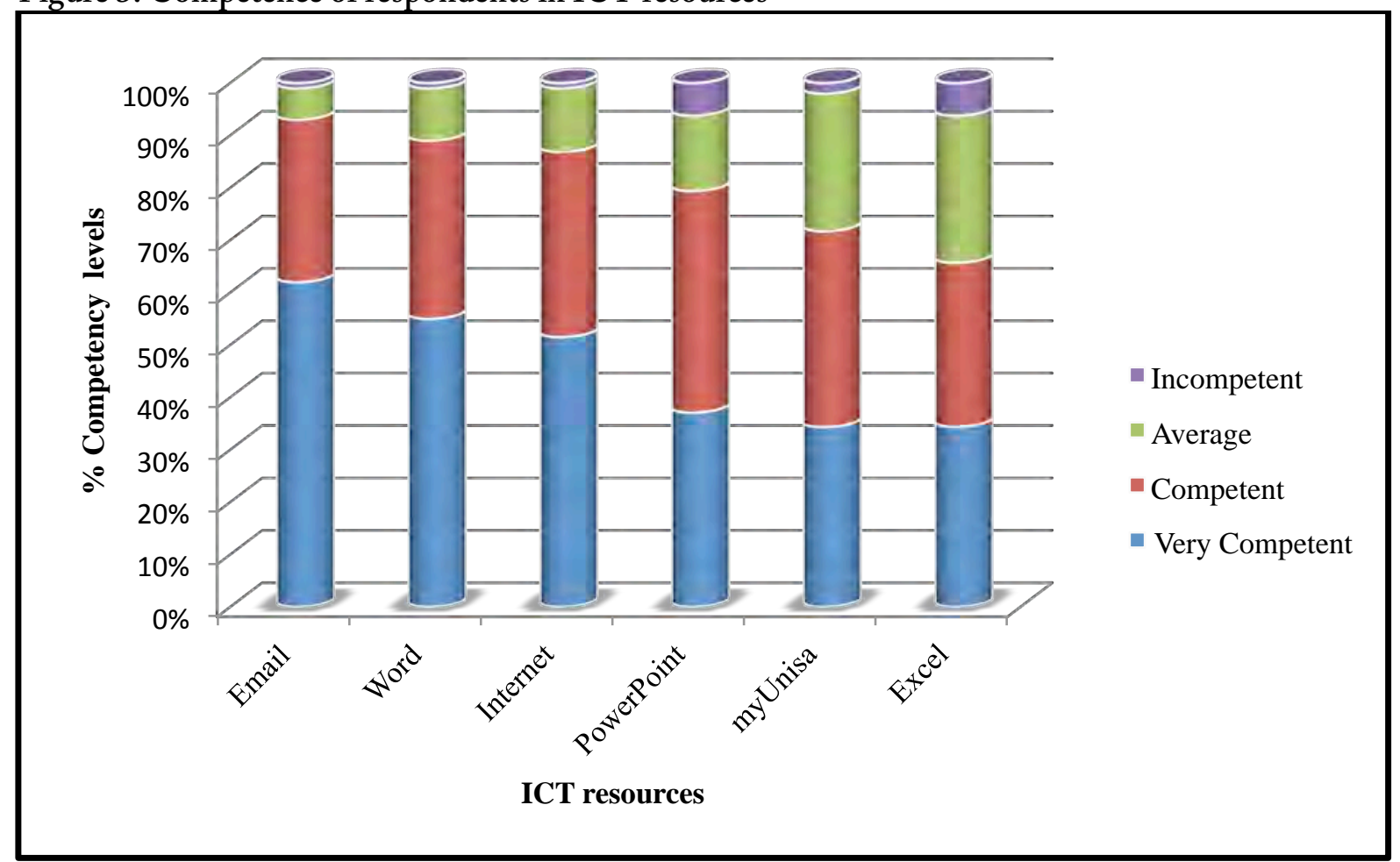

The resources which most of the respondents were competent in were:

- Email (93.0\%)

- Word (89.1\%)

- Internet (86.9\%)

It can be noted that respondents indicated competences that were more than $60 \%$ in all the ICT resources. However, it was worrying that there was a high percentage $(26.3 \%)$ of academics indicating average competence on the use of myUnisa. This is because myUnisa is the primary UNISA resource that academics should be well versed with in their teaching and academic administration.

In terms of emerging e-learning technologies that the respondents were aware of, there were 99 valid responses. This was a multiple response question, where more than one emerging technology could be indicated. The results are shown in Table 5. In terms of emerging elearning technologies that the respondents were currently using, there were 98 valid responses. The data is also presented in Table 5. 
Table 5: Awareness $(\mathrm{N}=99)$ and Use $(\mathrm{N}=98)$ of emerging technologies by the respondents

\begin{tabular}{|l|l|l|l|l|}
\hline Emerging Technology & $\begin{array}{l}\text { Awareness: } \\
\text { No of } \\
\text { respondents }\end{array}$ & $\begin{array}{l}\text { \% of } \\
\text { cases }\end{array}$ & $\begin{array}{l}\text { Use: } \\
\text { No of } \\
\text { respondents }\end{array}$ & $\begin{array}{l}\text { cof } \\
\text { cases }\end{array}$ \\
\hline Cell/mobile phones and devices & 95 & 96.0 & 81 & 82.7 \\
\hline $\begin{array}{l}\text { Open Access Technologies e.g. myUnisa, } \\
\text { Blackboard }\end{array}$ & 92 & 92.9 & 89 & 90.8 \\
\hline Social Networking Sites e.g. Facebook & 89 & 89.9 & 47 & 48.0 \\
\hline Blogs & 85 & 85.9 & 15 & 15.3 \\
\hline Video games & 81 & 81.8 & 18 & 18.4 \\
\hline Microblogging platforms e.g. Twitter & 80 & 80.8 & 15 & 15.3 \\
\hline Wikis and Wiki books & 78 & 78.8 & 19 & 19.4 \\
\hline $\begin{array}{l}\text { Open Educational Resources and Pod and video } \\
\text { casts }\end{array}$ & 68 & 68.7 & 29 & 29.6 \\
\hline Virtual characters, Avatars & & & & \\
\hline Pod usage production models & 50 & 50.5 & 6 & 6.1 \\
\hline Virtual worlds e.g. The Sims online & 43 & 43.4 & 6 & 6.1 \\
\hline Data Mashups & 38 & 38.4 & 6 & 6.1 \\
\hline Online grassroots video & 34 & 34.3 & 10 & 10.2 \\
\hline Pedagogical Agents e.g. Adele & 15 & 15.2 & 2 & 2.0 \\
\hline Skype & 9 & 9.1 & 2 & 2.0 \\
\hline Digital libraries & 2 & 2.0 & 2 & 2.0 \\
\hline Webinar & 1 & 1.0 & - & - \\
\hline
\end{tabular}

From the emerging e-learning technologies provided in the survey, awareness percentages of $50 \%$ or more are indicated in Figure 4 . With the exception of Cell/mobile phones and devices (82.7\%) and Open Access Technologies (90.8\%), the utilisation of all the other technologies was less than $50 \%$ as shown in Figure 4.

Figure 4: Awareness and use

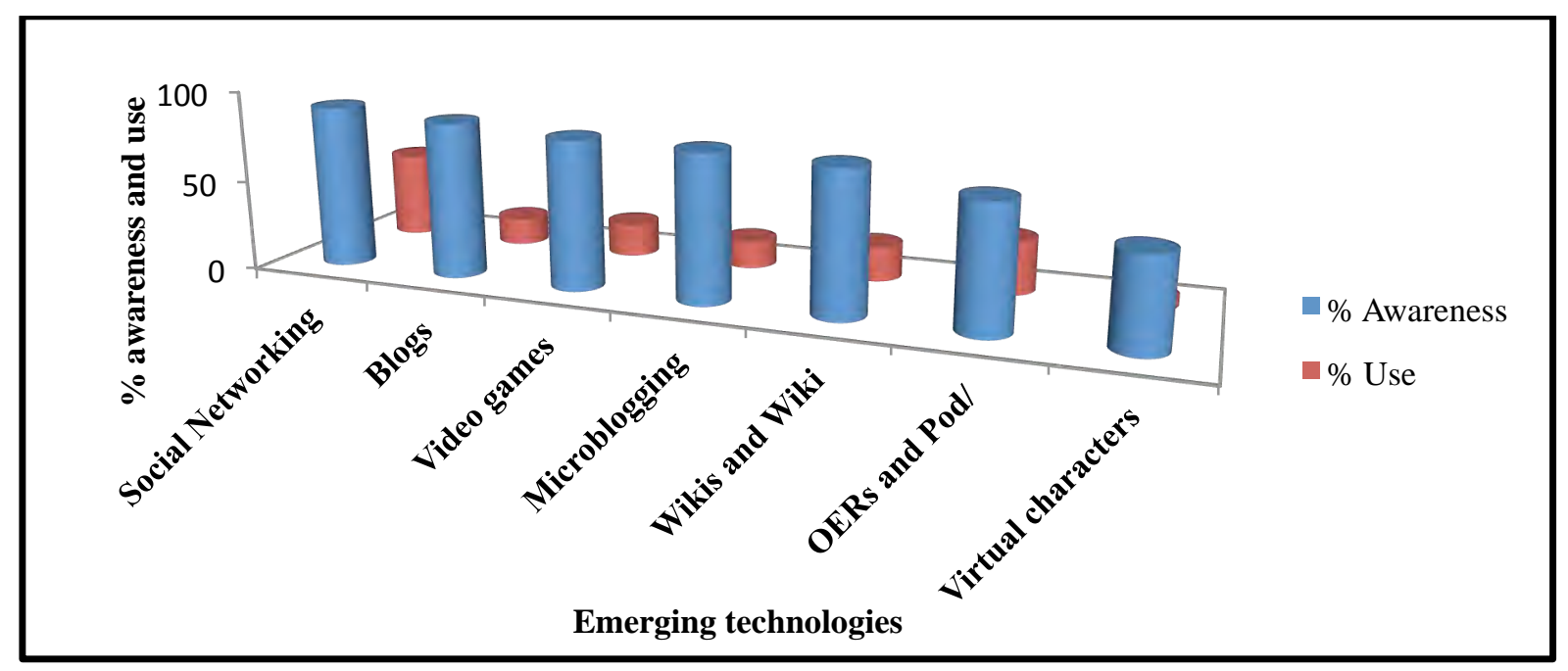

It can be seen from Figure 4 that, while technology awareness was high, usage was much lower for most technologies. Awareness of the technologies therefore does not necessarily 
translate to usage. Table 6 shows the technologies in use by the respondents in the different schools.

Table 6: Technologies in use by different respondents in the different Schools

\begin{tabular}{|c|c|c|c|c|c|c|c|c|c|c|c|c|c|c|}
\hline & \multicolumn{14}{|c|}{ Technologies in use } \\
\hline 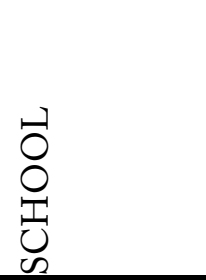 & $\begin{array}{l}\infty \\
\stackrel{\infty}{0} \\
0\end{array}$ & 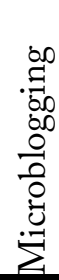 & $\frac{3}{3}$ & 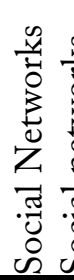 & 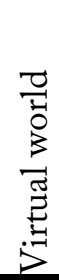 & $\frac{8}{\mathbb{8}}$ & 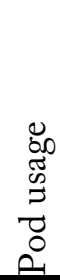 & 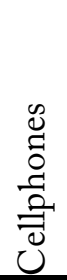 & 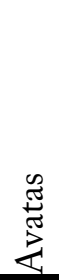 & 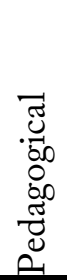 & 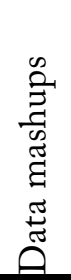 & 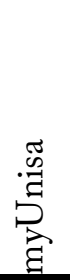 & 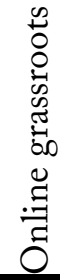 & $\begin{array}{l}\frac{1}{1} \\
0\end{array}$ \\
\hline Science & 3 & 2 & 3 & 14 & 1 & 6 & 1 & 16 & 2 & 1 & 0 & 19 & 0 & 8 \\
\hline Computing & 9 & 9 & 11 & 13 & 1 & $\overline{10}$ & 2 & 29 & 4 & 0 & 9 & 33 & 1 & 11 \\
\hline Arts & 10 & 8 & 15 & 22 & $\overline{0}$ & 6 & 4 & 29 & 2 & 1 & 1 & 30 & 1 & 14 \\
\hline
\end{tabular}

From Table 6, it is clear that the emerging e-learning technology that academics in the School of Computing used more than academics in the other Schools was Data mashups. Social Networks and Wikis were used more in the Arts than the Science and Computing Schools. Generally, Blogs, Wikis and Microblogging were less used by the respondents in the School of Science than they were used in Arts and Computing Schools. The frequencies of usage of the emerging e-learning technologies by the respondents are presented in Table 7.

Table7: Frequency of usage of emerging e-learning technology

\begin{tabular}{|l|l|l|l|l|}
\hline \multirow{2}{*}{ Emerging technology } & \multicolumn{4}{l|}{ Frequency of use } \\
\cline { 2 - 5 } & Everyday & $\begin{array}{l}\text { Once a } \\
\text { week }\end{array}$ & $\begin{array}{l}\text { Once } \\
\text { two weeks }\end{array}$ & Once a month \\
\hline Cell/mobile phones and devices & $81.3 \%(61)$ & $4.0 \%(3)$ & $5.3 \%(4)$ & $9.3 \%(7)$ \\
\hline Virtual characters, Avatars & $75.0 \%(3)$ & $25.0 \%(1)$ & - & - \\
\hline $\begin{array}{l}\text { Open Access Technologies e.g. } \\
\text { myUnisa, Blackboard }\end{array}$ & $54.7 \%(41)$ & $20.0 \%(15)$ & $16.0 \%(12)$ & $9.3 \%(7)$ \\
\hline Microblogging platforms e.g. Twitter & $38.5 \%(5)$ & $30.8 \%(4)$ & $23.1 \%(3)$ & $7.7 \%(1)$ \\
\hline Pedagogical Agents & $33.3 \%(1)$ & $33.3 \%(1)$ & $33.3 \%(1)$ & - \\
\hline Wikis and Wiki books & $29.2 \%(7)$ & $37.5 \%(9)$ & $20.8 \%(5)$ & $12.5 \%(3)$ \\
\hline Social Networking Sites e.g. Facebook & $26.1 \%(12)$ & $39.1 \%(18)$ & $19.6 \%(9)$ & $15.2 \%(7)$ \\
\hline Data mashups & $25.0 \%(2)$ & $25.0 \%(2)$ & $50.0 \%(4)$ & - \\
\hline Online grassroots video & $25.0 \%(1)$ & $25.0 \%(1)$ & $50.0 \%(2)$ & - \\
\hline $\begin{array}{l}\text { Open Educational Resources and Pod } \\
\text { and video casts }\end{array}$ & $15.2 \%(5)$ & $33.3 \%(11)$ & $21.2 \%(7)$ & $30.3 \%(10)$ \\
\hline Blogs & $11.5 \%(3)$ & $23.1 \%(6)$ & $15.4 \%(4)$ & $50.0 \%(13)$ \\
\hline Video games & $5.9 \%(1)$ & $17.6 \%(3)$ & $11.8 \%(2)$ & $64.7(11)$ \\
\hline Virtual worlds e.g. The Sims online & - & $66.7 \%(2)$ & $33.3 \%(1)$ & - \\
\hline Pod usage production models & - & $50.0 \%(5)$ & $40.0 \%(4)$ & $10.0 \%(1)$ \\
\hline
\end{tabular}

The emerging e-learning technologies that the majority of the respondents tended to use every day were:

- Cell/mobile phones and devices (81.3\%)

- Open Access Technologies e.g. myUnisa, Blackboard (54.7\%) 
- Social Networking Sites e.g. Facebook (26.1\%)

Additionally, some respondents mentioned Skype and Google Chat as the other technologies they frequently used. The areas of use of the different technologies by the respondents are shown in Figure 5a and Figure 5b. This was a multiple response question. The results show well-distributed responses for the different uses.

\section{Figure 5a: Use of technology}

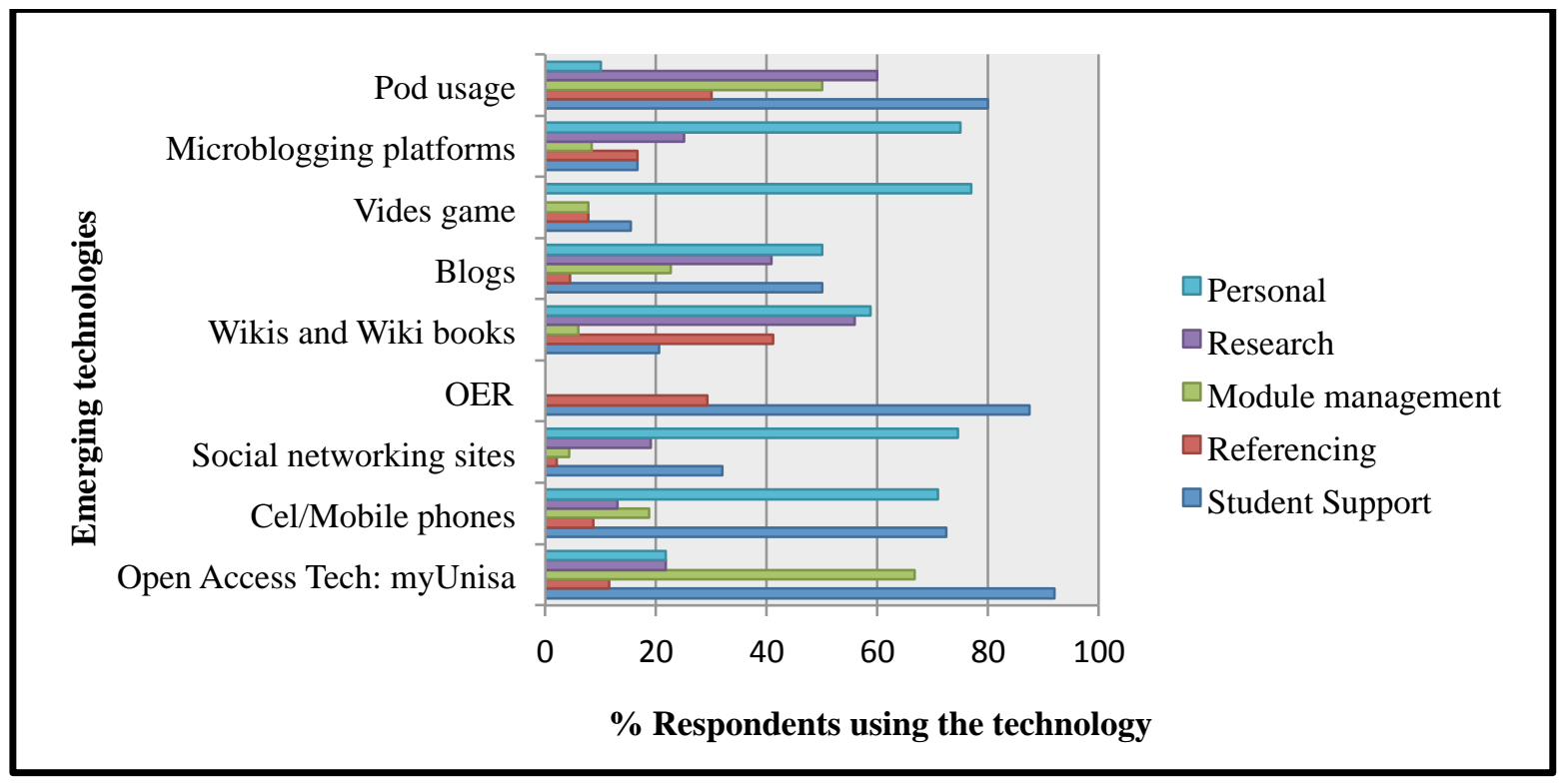

Figure $15 \mathrm{~b}$ : Areas of use of technologies

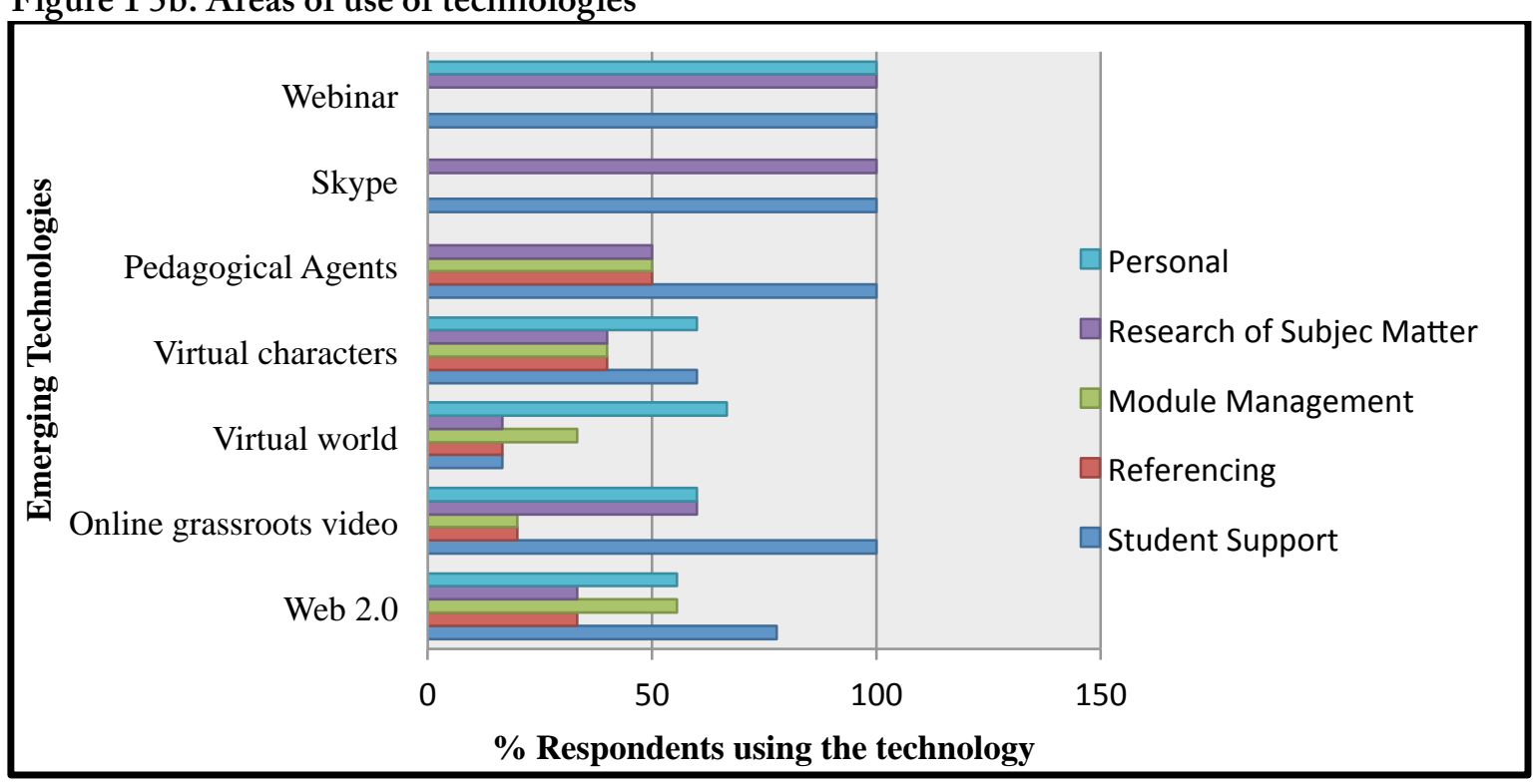

From the results in Figures 5(a) and 5(b), the majority of the respondents used Open Educational Resources and Pod and video casts, social networking sites, Open Access Technologies, Cell/mobile phones and devices, and Blogs for student support. The most used service for module management was Open Access Technologies. The technologies used mostly in research matters were social networks, Wikis and Wiki books, Open Access Technologies and blogs. Other uses included email, Skype, Webinar and Web browsing. 
From the results shown in both figures, Video games, Social Networking Sites e.g. Facebook, Cell/mobile phones and devices, Wikis and Wiki books, Open Access Technologies, Cell/mobile phones and devices, and Blogs were used more for personal use than academic applications. As expected, the UNISA official platform, myUnisa, was the most used technology across the different applications. The perceived benefits of emerging technologies in tuition are shown in Table 8.

Table 8: Perceived benefits of emerging technologies

\begin{tabular}{|c|c|c|c|c|c|}
\hline \multirow[t]{2}{*}{ Perceived Benefit } & \multicolumn{5}{|c|}{ Level of Agreement } \\
\hline & 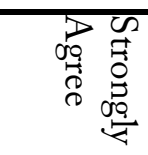 & 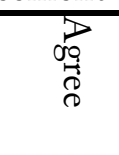 & 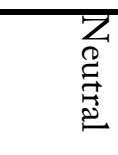 & 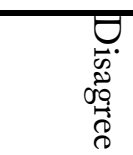 & 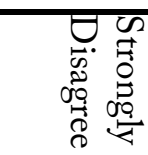 \\
\hline Offers teaching place flexibility & $\begin{array}{l}34.0 \% \\
(34)\end{array}$ & $\begin{array}{l}49.0 \% \\
(49)\end{array}$ & $\begin{array}{l}13.0 \% \\
(13)\end{array}$ & $\begin{array}{l}2.0 \% \\
(2)\end{array}$ & $\begin{array}{l}2.0 \% \\
(2)\end{array}$ \\
\hline Offers teaching time flexibility & $\begin{array}{l}32.3 \% \\
(31) \\
\end{array}$ & $\begin{array}{l}49.0 \% \\
(47) \\
\end{array}$ & $\begin{array}{l}13.5 \% \\
(13)\end{array}$ & $\begin{array}{l}3.1 \% \\
(3) \\
\end{array}$ & $\begin{array}{l}2.1 \% \\
(2)\end{array}$ \\
\hline $\begin{array}{l}\text { The use of technology cuts the } \\
\text { distance between student and } \\
\text { lecturer }\end{array}$ & $\begin{array}{l}(38.4 \%) \\
(38)\end{array}$ & $\begin{array}{l}42.4 \% \\
(42)\end{array}$ & $\begin{array}{l}15.2 \% \\
(15)\end{array}$ & $\begin{array}{l}3.0 \% \\
(3)\end{array}$ & $\begin{array}{l}1.0 \% \\
(1)\end{array}$ \\
\hline $\begin{array}{l}\text { Increased information access } \\
\text { and distribution }\end{array}$ & $\begin{array}{l}43.0 \% \\
(43) \\
\end{array}$ & $\begin{array}{l}36.0 \% \\
(36)\end{array}$ & $\begin{array}{l}15.0 \% \\
(15)\end{array}$ & $\begin{array}{l}2.0 \% \\
(2)\end{array}$ & $\begin{array}{l}4.0 \% \\
(4)\end{array}$ \\
\hline Offers better student support & $\begin{array}{l}23.7 \% \\
(23)\end{array}$ & $\begin{array}{l}51.5 \% \\
(50)\end{array}$ & $\begin{array}{l}13.4 \% \\
(13)\end{array}$ & $\begin{array}{l}11.3 \% \\
(11)\end{array}$ & - \\
\hline Environmental friendly & $\begin{array}{l}26.8 \% \\
(26) \\
\end{array}$ & $\begin{array}{l}43.3 \% \\
(42)\end{array}$ & $\begin{array}{l}21.6 \% \\
(21)\end{array}$ & $\begin{array}{l}5.2 \% \\
(5)\end{array}$ & $\begin{array}{l}3.1 \% \\
(3)\end{array}$ \\
\hline Saves on resources & $\begin{array}{l}30.6 \% \\
(30) \\
\end{array}$ & $\begin{array}{l}34.7 \% \\
(34)\end{array}$ & $\begin{array}{l}21.4 \% \\
(21)\end{array}$ & $\begin{array}{l}10.2 \% \\
(10)\end{array}$ & $\begin{array}{l}3.1 \% \\
(3)\end{array}$ \\
\hline $\begin{array}{l}\text { Fast and efficient way of } \\
\text { teaching }\end{array}$ & $\begin{array}{l}23.5 \% \\
(23)\end{array}$ & $\begin{array}{l}40.8 \% \\
(40)\end{array}$ & $\begin{array}{l}26.5 \% \\
(26)\end{array}$ & $\begin{array}{l}8.2 \% \\
(8)\end{array}$ & $\begin{array}{l}1.0 \% \\
(1)\end{array}$ \\
\hline Cost effective & $\begin{array}{l}20.2 \% \\
(20) \\
\end{array}$ & $\begin{array}{l}35.4 \% \\
(35)\end{array}$ & $\begin{array}{l}27.3 \% \\
(27)\end{array}$ & $\begin{array}{l}14.1 \% \\
(14)\end{array}$ & $\begin{array}{l}3.0 \% \\
(3)\end{array}$ \\
\hline $\begin{array}{l}\text { Enhancing student's problem } \\
\text { solving abilities }\end{array}$ & $\begin{array}{l}11.3 \% \\
(11)\end{array}$ & $\begin{array}{l}32.0 \% \\
(31)\end{array}$ & $\begin{array}{l}43.3 \% \\
(42)\end{array}$ & $\begin{array}{l}8.2 \% \\
(8)\end{array}$ & $\begin{array}{l}5.2 \% \\
(5)\end{array}$ \\
\hline Cuts on administrative process & $\begin{array}{l}20.2 \% \\
(20)\end{array}$ & $\begin{array}{l}26.3 \% \\
(26)\end{array}$ & $\begin{array}{l}23.2 \% \\
(23)\end{array}$ & $\begin{array}{l}19.2 \% \\
(19)\end{array}$ & $\begin{array}{l}11.1 \% \\
(11)\end{array}$ \\
\hline
\end{tabular}

The perceived benefits of emerging technologies with a level of agreement of more than $70 \%$ were:

- Teaching place flexibility $(83.0 \%)$

- Teaching time flexibility (81.2\%)

- The use of technology cuts the distance between student and lecturer (80.8\%)

- Increased information access and distribution (79.0\%)

- Offers better student support (75.3\%)

- Environmentally friendly (70.1\%).

Perceived benefits which had a level of agreement of less than $50 \%$ were:

- Enhancing student's problem solving abilities (43.3\%)

- Cuts on administrative process (46.5\%). 
The other benefits further mentioned by the respondents, which were not on the list, were that emerging technologies engaged students in active learning and some were affordable in terms of easy access to some online resources.

\section{Technology adoption readiness and willingness}

Respondents were asked to give their agreement level on readiness and willingness (Figure 6).

Figure 6: Technology readiness and willingness

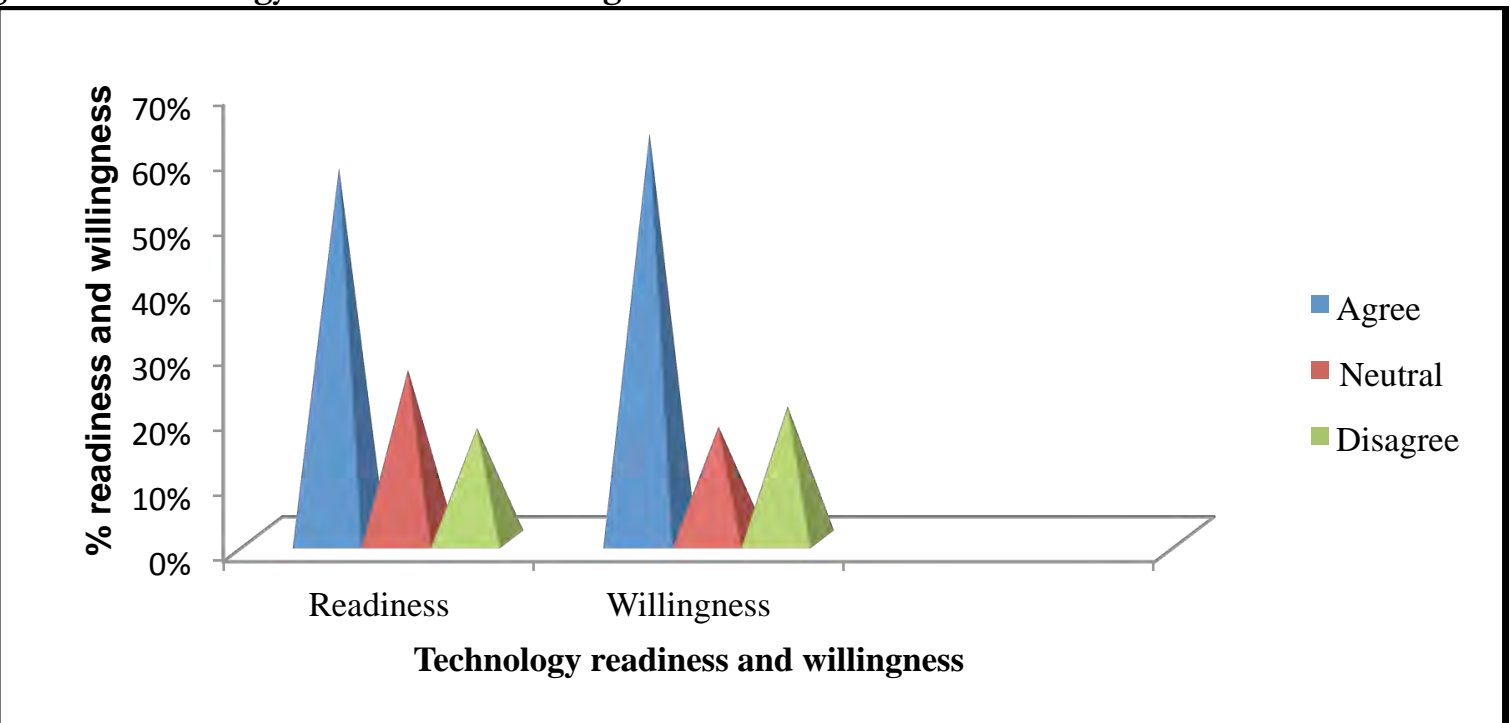

From Figure 6, it can be seen that there was a higher level of willingness to migrate to elearning based teaching completely $(62.3 \%)$ than readiness, which was at $57 \%$. The neutral responses of $17.3 \%$ for willingness and $26 \%$ for readiness showed that a significant number of academics were undecided. The group of neutral responses and those who disagreed presented a large pool of potential willing and ready adopters, depending on how easily their mind set could be swayed towards technology adoption.

From the other indicator questions related to readiness and willingness, the following indicators had a level of agreement of more than 50\%:

- I am willing to learn new technological approaches for teaching (86.0\%)

- I require online tutorial training (64.3\%)

- Emerging technology is positively improving the way I teach (60.6\%)

- I am competent in using these technologies for research $(60.4 \%)$

- Emerging technology is positively improving the way my students learn (50.5\%)

- Students' availability and access is a problem (64.9\%)

While several readiness and willingness indicators had a level of agreement of more than $50 \%$, there were a high number of neutral responses on:

- The relevance of emerging technologies to their subject areas of teaching (20.2\%),

- a lack of knowledge of opportunities that new technologies offer to teaching (32.7\%),

- lack of knowledge on preparing e-learning teaching materials (31.3\%),

- how emerging technology positively improve their throughput (55.1\%),

- the use of emerging technology takes more of my time than traditional methods would do 
- (39\%),

- emerging technology positively improve the way my students learn (39\%) and,

- emerging technology creating information of lasting value (39\%).

The result where most respondents seem not to give a clear response shows the uncertainty that exists amongst academics with respect to their willingness to adopt technology.

Academics showed willingness to migrate fully to e-learning of $68.1 \%, 56.4 \%$ and $62.5 \%$ for Science, Computing and Arts, respectively. The respondents' willingness to learn was 100\% for Arts, $95.4 \%$ for Science and 58.9\% for Computing. It can be seen that the academics in the schools of Arts and Science were more willing to learn than those in the School of Computing. When linking this to technologies being used, one conclusion that can be drawn is that, by virtue of being in Computing, the academics in the School of Computing were probably already aware and competent in the technologies, that they did not find it too compelling to learn more about the emerging technologies.

The respondents also indicated other comments regarding their readiness and willingness in adopting emerging e-learning technology-based methods in tuition. These comments are presented in Table 9.

Table 9: Additional comments on readiness and willingness in adopting emerging e-learning technology $(\mathrm{N}=53)$

\begin{tabular}{|l|l|l|}
\hline Comments & $\begin{array}{l}\text { No of } \\
\text { Respondents }\end{array}$ & $\begin{array}{l}\% \text { of } \\
\text { case }\end{array}$ \\
\hline Problems with platforms like myUnisa which are not stable. & 14 & 36.8 \\
\hline Willing to adopt the technologies with conditions. & 10 & 26.3 \\
\hline People should have enough access to the resources to be able to use them. & 6 & 15.8 \\
\hline Availability of staff to use these technologies. & 5 & 13.2 \\
\hline $\begin{array}{l}\text { Emerging technologies change rapidly and this may mean always } \\
\text { spending time working on new stuff. }\end{array}$ & 3 & 7.9 \\
\hline I prefer to stick to traditional ways of teaching. & 3 & 7.9 \\
\hline It is not time saving. & 2 & 5.3 \\
\hline Use online resources. & 2 & 5.3 \\
\hline Clear guidelines as of what is expected. & 1 & 2.6 \\
\hline Students in rural areas are marginalised by these technologies. & 1 & 2.6 \\
\hline Technologies not user friendly to some modules. & 1 & 2.6 \\
\hline Technologies should start at primary level. & 1 & 2.6 \\
\hline Technology is only a tool. & 1 & 2.6 \\
\hline Ensuring authenticity is a big problem in any ODL assessment. & 1 & 2.6 \\
\hline Diversity & 1 & 2.6 \\
\hline Lecturers, see for what works. & 1 & 2.6 \\
\hline
\end{tabular}

Stability problems of e-learning platforms such as myUnisa were indicated as a major concern. Respondents also felt that they were willing to adopt emerging technologies but with some conditions. However, these were not further elaborated here. 


\section{Discussion}

Integrating emerging technologies in teaching and learning is vital when considering that educational institutions cannot escape the fact that migration to online learning is a reality in this technological era. In supporting teaching and learning, UNISA endeavours to embed elearning in their academic teaching and administration (UNISA curriculum policy, 2012). With this advocacy, all academics are required to play an important role in the integration of ICTs in teaching. There is a need for academics to accept and adopt emerging technologies for effective implementation of online teaching.

This study, focusing on UNISA academics' use, knowledge, and adoption of emerging technologies in teaching, showed a high level of knowledge and usage of ICT resources such as emails, MS Word, Internet, MS Excel and Open Access Technologies (myUnisa in the case of UNISA). The study also revealed that awareness was high, with most emerging elearning technologies having a high percentage of responses of above $80 \%$. This can be taken as an indicator of a strong technological background across the Schools studied. However, some technologies such as Pedagogical agents, Skype, and Webinar, were less commonly known to academics. This can be attributed to the fact that these were not common UNISA ICT resources. According to Panda \& Mishra (2007), a good technological base is seen as a pre-requisite for one's willingness and readiness to migrate towards e-learning.

It should be noted, however, that knowledge of a technology does not necessarily translate to increased usage. While the frequency of use was high amongst the respondents for the two ICT resources - mobile devices and open access technologies - the frequency of everyday usage was not as high for all the other ICT resources. Academics tended to use the technologies they required for everyday social and academic engagements most, and they became more competent in these. The most common areas of technology use showed that academics actively used technologies for student support, module support and personal use. Educause (2003) reported that these were the basic areas of technology application in academia and it is hoped that as the academics continue to use and become more proficient in these areas, their confidence to move towards other more academic applications will grow. The areas of use of myUnisa, Pod and video casts and cell phone mainly showed that academics were aware that the University required them to use such technologies for student support. The use of myUnisa in student support and module management and administration is generally prescribed and as such, it is not surprising that this platform received the most positive use response.

Uncertainty as to the importance and relevance of emerging technologies is an important aspect of adoption (Veletsianos, 2010). From the analysis of the perceived benefits that these technologies brought, place, distance and time flexibility ranked the highest while the benefits that emerging technologies enhanced student problem-solving and cuts on the administrative costs ranked lowest. It can be concluded still, that the respondents positively perceived the benefits that emerging technologies brought to academia and this related well to responses on willingness and readiness by academics to go online fully. However, it must be noted that there were reservations amongst the respondents as to how emerging technologies will enhance students' problem solving abilities.

Considering the society in which we live and the direction technology is going, academics should be willing and ready to adopt technology relevant to their disciplines. From the results of this study, it can be noted that many academics were willing to use technologies for full online teaching $(62.3 \%)$. Furthermore, $86.0 \%$ of the respondents indicated willingness to 
learn new approaches for teaching. These results are encouraging and it is hoped that with such willingness, academics will be more accepting toward and ready for e-learning. There is however, a need to convince and train those lagging behind on the use of technology. As with all innovation, once all stakeholders mastered the new approaches they will easily come on board (Dede, 1999; Summaka et al., 2010).

Studies by Kumar et al. (2008) showed that there was a positive relationship between attitude and usage, acquiring and integration of knowledge and skills for e-learning. In this study, academics from different faculties understood the benefits and/or importance of using emerging technologies and responded appropriately. There is also a need here to accept the utility, relevance and use of emerging technologies. There were some concerns amongst the respondents, which included issues of authenticity and the ability to think and work independently in practice. Student availability was also expressed as a concern by $64 \%$ of the academics. It was felt, furthermore, that emerging technologies might increase disparities among subgroups of students, e.g. those in rural areas might be disadvantaged. Moreover, the respondent academics indicated that they were willing to adopt the technologies given a series of conditions. It is imperative that further studies evaluate such conditions and their potential relevance for adoption.

Veletsianos (2010) echoed that there was need to be cognisant of the fact that resistance and failures are possible with emerging technology use in education, and, it will be helpful if this is documented in the literature. The indication by some academics that they did not know how to prepare material for e-learning and they needed training meant that staff will require support with their e-learning teaching activities. Educause (2003) indicated that e-learning presented a need for a range of support needs, and that institutions must provide the appropriate resources to address them. To this end, UNISA has designed and is implementing a number of professional development workshops and training designed to enable academics to be very competent in e-learning. In its revised curriculum policy (2012), UNISA seems committed to ensuring that employees and students (where appropriate) receive adequate training to play their part in the development, implementation and experience of e-learning/m-learning across the University (UNISA curriculum policy, 2012).

Educause (2003) and Morgan (2003) indicated that department area and subject matter can affect technical proficiency with some technology tools. In this study, the academics in the School of Science gave the highest indication of their willingness to migrate to e-learning followed by Arts and lastly the School of Computing. No direct relationship could be established as to the relationship of readiness and willingness to discipline area and school, as similar responses were obtained across Schools. The higher indication of willingness to learn as given by academics in Science and Arts, compared to those in Computing, could also be indicative of their being less conversant with these technologies than colleagues in Computing such that they were willing to learn more. Indeed, it is possible that a more positive perception of the use of ICT in education leads academics to experiment more with these technologies, leading to more experience with it (Dede, 1999, Dede, 2004; Summaka et al., 2010).

\section{Conclusion}

Taylor (1999) echoed the fact that as the world has fast entered into the information era and economy, demands are being placed on higher education delivery to be more flexible and offer lifelong learning. There is widespread scepticism as to whether educational systems will 
be able to overcome their traditional inertia and respond to the challenge of the knowledgebased revolution (Taylor, 1999; Alshemmary, 2012). From the results of this study, it can be seen that the respondent academics were not opposed to adopting e-learning. There is sufficient knowledge and understanding of the benefits of e-learning, and a healthy willingness to employ emerging technologies for teaching. From these results, the usage of technology was not related to the academic school or teaching area of the respondents. The choice and use of some technologies could be linked to academics use in the different Schools. For example, Data mashups were the most used by respondents from the School of Computing.

Considering the gap between awareness and use of technologies observed in this study, there is a need to evaluate and address why academics were not using the technologies that they were aware of. Further training on the different applications of the less used technologies at UNISA is recommended. Also considering the high neutral and disagreement responses obtained on some of the indicators, it would be essential for further studies to look into the reasons why the academics expressed these notions and the necessary measures implemented to ensure successful emerging e-learning technologies adoption at UNISA.

\section{References}

Ahmad, A. R., Basir, O. \& Hassanein, K. (2004). Adaptive User Interfaces for Intelligent Elearning: Issues and Trends. In: 4th International Conference on Electronic Business. Beijing, pp.925-934.

Ahmand, A. R., Basir, O., \& Hassanein, K. (2004). Adaptive User Interfaces for Intelligent E-Learning: Issues and Trends / Beijing. The Fourth International Conference on Electronic Business (ICEB2004). Beijing.

AR, A., O, B., \& K, H. (2004). Adaptive user interfaces for intelligent e-learning: Issues and trends. 4th International Conference on Electronic Business, (pp. 925-934). Beijing.

AlShemmary, E. A., Niir, B. D., \& Katheeth, Z. D. (2012). Reality of E-Learning and its application within the University of Kufa. Advances in Computer Science and its Applications (ACSA) , 1 (3), 215-221.

Anand, R., Saxena, S., \& Saxena, S. (2012, 05 07). E-learning and its Impact on Rural Areas. Retrieved 06 10, 2012 from MECS(/). DOI: 10.5815/ijmecs: http://www.mecspress.org

Annon. (2003). Impact and challenge of E-learning. Retrieved 03 12, 2013 from Educase Vol 3: supporting E-learning in higher education: http://net.educause.edu/ir/library/pdf/ers0303/rs/ers03036.pdf

Arthur, L., Beecher, B., Elliot, R., \& Newman, L. (2006). ELearning: Do our students want it and do we care. . Retrieved 02 04, 2012 from (Proceedings of the 23rd annual ascilite conference: Who is learning? Whose technology?): http://www.ascilite.org.au/conferences/sydney06/proceeding/pdf_papers/p192.pdf

Delich, P., Kelly, K., \& McIntosh, D. (2008). Emerging technologies in e-learning. In S. Hirtz, D.G. Harper, and S. Mackenzie (Eds) Education for a Digital World: Advice, Guidelines, and Effective Practice from Around the Globe , 1 (3), 5-22. 
Dede, C. (2004). Enabling Distributed-Learning Communities via Emerging Technologies. Proceedings of the 2004 Conference of the Society for Information Technology in Teacher Education (SITE) (pp. 3-12). Charlottesville: American Association for Computers in Education.

Hegarty, B., Penman, M., Coburn, D., Kelly, O., Brown, C., Gower, B., et al. (2003). ELearning adoption: staff development and self efficacy. Proceedings of the 23rd annual ascilite conference: Who is learning? Whose technology? (pp. 156-166). Sydney: Sydney University Press.

Hegarty, B. (2004). The impact of technology on the quality of teaching and learning in tertiaryInstitutions: Literature review. Project completed as part of the requirements for a Doctorate in Education. University of Wollongong, NSW.

Hegarty, B., Penman, M., Brown, C., Gower, B., Coburn, D., Kelly, O., et al. (2005). Approaches and implications of eLearning adoption on academic staff efficacy and working practice: Final report. Universal College of Learning (UCOL), Palmerston North, New Zealand.

Kumar, N., Rose, R. C., \& D’Silva, J. L. (2008). Teachers' Readiness to Use Technology in the Classroom: An Empirical Study. European Journal of Scientific Research , 21 (4), 603-616.

Lucas, B. (2006). Bringing e-learning home: An experiment in embedding e-learning using e-learning using departmental e-learning advocates. . Proceedings of the 23rd annual ascilite conference: who's learning? Whose technology? (pp. 479-482). Sydney: Ascilite.

Morgan, G. (2003). Faculty Use of Course Management Systems . Boulder, Colo.: EDUCAUSE Center for Applied Research , 2, 76.

Queirós, R., Pinto, M., Rodrigues, A., Babo, R., Lopes, A., \& Coelho, P. (20). Differences in Internet and LMS usage - A Case Study in Higher Education. Retrieved 03 12, 2013 from IGI

Global: http://www.linooliveira.com/publicacoes/LO_ECEL2010_Paper.pdf

Panda, S., \& Mishra, S. (2007). E-Learning in a Mega Open University: Faculty attitude, barriers and motivators. Educational Media International , 44 (4), 323-338.

Siemens, G., \& Tittenberger, P. (2009, March 20). Handbook of emerging technologies for learning.

Summaka, M. S., Baglibel, M., \& Samancioglu, M. (2010). Technology readiness of primary school teachers: A case study in Turkey . Procedia Social and Behavioural Sciences , 2 (2), 2671-2675.

UNISA Revised Curriculum Policy. Section 5.7.2. p 17-18. (2012). Pretoria: UNISA.

Veletsianos, G. (2010). A Definition of Emerging Technologies for Education. Athabasca: Athabasca University Press.

Wang, F., \& C, R. T. (2003). Why Do Teachers Need to Use Technology in Their Classrooms? Issues, Problems, and Solutions. Computers in the Schools , 20 (4), 49-65.

(n.d.).

Woodill, G. (2006). Emerging E-Learning Technologies: Tools for Developing Innovative Online Training. Brandon Hall Research. Available from: 
<http://courseware.hbs.edu/demo/new_wave/EmergingTechnologies. pdf> [Accessed 31 July 2013]. 